STUDIA PRAWNO-EKONOMICZNE, t. CV, 2017

PL ISSN 0081-6841; e-ISSN 2450-8179 $\quad$ s. 23-44

DOI: $10.26485 /$ SPE/2017/105/2

Natali LEVIN*

\title{
TORTS IN ISRAELI LAW. MEDICAL MALPRACTICE AND NONPECUNIARY HARM
}

\begin{abstract}
(Summary)
This article discusses a complicated and cumbersome aspect - nonpecuniary harm of the type known to all of us as pain and suffering. As of today, there are no well-defined legal standards on the evaluation of nonpecuniary harm in general and of the type of pain and suffering in particular. Consequently, we find rulings of damages that are significantly different between the harmed parties, even in circumstances under which the harms are similar. The matter of every harmed party is individual, and the question of the harm is unique to his or her lifestyle. The economic approach to law teaches that the guiding principle in torts is justice that remedies the harm in an equal manner, and thus certainty in law is obtained. However, in the absence of well-defined legal standards, the economic approach is unachievable. One possible solution to this situation is that the types of harms and the types of harmed people could be the deciding factor in the amount of compensation, therefore it is necessary to estimate, evaluate, and quantify this in numerical, financial terms.
\end{abstract}

Keywords: Torts; Medical malpractice in Israel; Pecuniary and Nonpecuniary Harm

\section{Introduction}

One of the most important institutions in pre-state Israel was that of public medicine, the apparatus of which was installed before the State was established. Over the years, the institution of medicine has changed beyond recognition, and under the public mission of this institution is a more private aspect, a symbol of the modern era, characterized by liberalism and the sanctification of individualism.

* PhD Student, Adam Mickiewicz University in Poznan, Department of Philosophy, Poland; e-mail: natalilaw50@gmail.com 
Israel's health system has seen a number of historic milestones in its development with many of her health organizations being established before the founding of the State. The ideological concept of the health fund 'Clalit', the first and for many years primary health fund, was based on the principles of equality and mutual assistance. These principles have left their imprint on the Israeli health care system for many years.

Within four years of the establishment of the state, Israel's population had doubled as a result of large waves of immigration. Increased immigration and rampant disease among immigrants created a deficiency in the health system, which the Health Ministry had no response to. The 'Clalit' Health Fund offered its services for the provision of healthcare for new immigrants and thus became the most dominant player in the supply of healthcare.

The National Health Insurance Law, which was enacted in January 1995, generated the most substantial change in the health system in the country.

The basis to the legislation came about in light of deficiencies that arose in the provision of services to the public and the substantial financial shortcomings of the 'Clalit' Health Fund.

The five underlying principles within the law included:

a) insurance for all,

b) freedom of choice of health fund,

c) the defining of a package of services,

d) the changing of the mechanism for the collection of funds,

e) change in the allocation of funds.

This change in the law was based on the values of justice, equality and mutual assistance whereby the state is responsible for ensuring public health services for its citizens. Another purpose of the law was to increase the sources of financing of the health system.

The current state of the health care system is based on a number of bodies: the Ministry of Health, the various health funds and institutions and private sector organizations.

The health system has to cope with financial distress, shortage of manpower, shortage of hospital beds alongside bureaucracy and constant social change that have led to a situation of multiple cases of medical malpractice in Israel.

The same holds true within the judicial institution and legal instruments in general, which address a steadily increasing extent of lawsuits against the medical institutions, on the part of the individual plaintiff. From an initial, non-professional perspective, it is possible to see a certain absurdity in such a situation, in that 
a person initiates a prosecution against somebody who has supposedly acted for his or her benefit, that had he not acted then the plaintiff would have remained in a poor condition. Moreover, the grounds of medical malpractice appear even more absurd, since they attack the medical institution for not doing for the plaintiff the best that could be done.

However, a professional, in-depth analysis indicates otherwise. Medical issues pertain to the person's body, and the institution of medicine, like any other institution, is intended for a purpose - it has a goal. The matters of the human body encompass many broad aspects, so many that it is not possible to delineate and define their scope.

This paper will discuss the complexity of nonpecuniary harm of the completely human type in the Israeli law system, which is commonly known as pain and suffering following injury to the human body.

As of now, there are no well-defined legal standards on the evaluation of nonpecuniary harm in general and of the type of pain and suffering in particular. Consequently, we find rulings of damages that are significantly different between harmed parties, even in circumstances under which the harms are similar.

The chief concern of this paper, therefore, is to provide arguments in favor of the standpoint that a) the amounts of compensation on topics of medical malpractice should not be limited and b) moreover, the tort of nonpecuniary harm should be developed. The general premise on which my argumentation is built is that the institution of medicine - and all therein that provides medical treatment for a person - is covered by insurance, the purpose of which is to pay the financial compensation to the harmed party in the end.

Despite the fact that in tort law the construction of reasons and the grounds on which one elaborates pain and suffering are complex, in this article, I will argue that compensation for pain and suffering for a person not only is appropriate in tort law but also is desired in our method of law in Israeli society.

\section{Aspects of Negligence and Medicine in Israeli Law}

The basic principle guiding medical negligence cases is that any person seeking medical treatment is entitled to receive treatment that guarantees their right to a full recovery, their right to dignity and privacy (which obligates medical personnel to medical confidentiality), and their right to autonomy and liberty (which requires their consent to for the treatment to be carried out). On the other hand, medical staff have the obligation to provide the most professional treatment 
possible and avoid the possibility of causing harm to their patients. Therefore, if negligent, reckless treatment by the medical staff causes harm to the patient, the latter is authorized to file a tort claim against the medical professional. The goal of filing the claim is to enable the receiving of compensation on account of the harm caused.

The court in Israel calculates the amount of compensation that is owed to the patient according to various criteria. These include: loss of working days, determining the extent of disability, the nature of the suffering that the patient is dealing with and more. The option of suing a negligent medical personnel adds another important purpose - that of deterrence and encouragement of appropriate conduct. The medical personnel understand that in order to avoid the demand for financial compensation and the damage to their reputation that comes with it, they must be professional and careful.

The matters of medical malpractice are not unique or independent in Israeli legislation and are based on sections 35 and 36 of an Ordinance that originated in the period of the British Mandate ${ }^{1}$. The establishment of the State of Israel in the year 1948 indicated the beginning of a new system, when serious economic issues were faced by the leadership. In the beginning, the social approach to the settlement of Israel was paramount and was expressed in the community medical constellation under the systems of medical clinics.

At that time, the feeling of Jewish collectivism was at its zenith, since the State of Israel was developing, which required contribution to the common goal ${ }^{2}$, more than the development of the well-being of individuals.

Consequently, for instance, the state did not adopt a single step to nationalize collective factories and in essence chose to cultivate them under the Histadrut - the General Organization of Workers in Israel. As state-building progressed, the legislature began with the creation of a medical system regarding the relations between the caregiver and the care receiver in the Patient's Rights Law ${ }^{3}$.

Today the privatization approach is felt in a variety of aspects of the management of the State and this does not necessarily mean that the state intervenes less in the supply of services but, that it enables itself to intervene sporadically, thus allowing the State to maintain control while creating a division between it and the recipients of the services. The result is that the State reduces

See: section 50 in general and subsection (3) in particular of the Civil Wrongs Ordinance, 1380, 1 (93) (A) 129.

2 M. Shalev, Political Economics, in: N. Berkovitz, U. Ram (eds.), Inequality Lexicon, BenGurion University Press, Beer Sheva 2006, pp. 204-211.

3 Patient's Rights Law of 1966, pp. 68, 327. 
its obligation to be accountable to its citizens, concurrent with the strengthening of the individual's autonomy.

The very existence of a normative outline is reflected also in powerful internal tension that often obligates difficult decisions, when the need arises to choose between the interests of the litigating individual and the interests of the public medical system, which ultimately is supported by the state and the sum of its citizens.

In the State of Israel, the current approach regarding medical malpractice is that this type of claim is desirable and even encouraged. However, there are objections to the approach that prevailed in the past which saw in the claim an obstacle to the daily business of medicine and an impediment to the development of medicine. An English Judge, Lord Denning ${ }^{4}$, ruled that society has an interest in as much transparent intervention as possible in the medical profession. He recognized an important social interest in regulating compensation to the victim in the case of damage as a result of medical negligence.

This approach was not accepted in England and, furthermore, the distinction between negligence and error of judgement was rejected. The accepted approach in most western countries is that the one must compensate for damage that is the fault of the harming party and, tort law has always stated that the harming party that caused damage must compensate the injured party.

Over the years, the law has developed with regards to concepts of modern justice and a demand began for the existence of guilt as a prerequisite for imposing liability.

In Israeli society, which holds the sanctity of life as a supreme value, the existence of an effective, objective monitoring mechanism, enshrined in the Civil Wrongs Ordinance is essential. This relies on civil negligence and is provided under the supervision of the Public Courts.

Indeed, this tension is not the exclusive province of medical law and it exists in all branches of law in the conflict between the individual's needs and the resources of the public system 5 . Thus, the legislator maintains the quality of the medical treatment provided to the patients and makes certain that the treatments for which there is a high chance of complication will be performed by professional physicians under supervision.

This is also the case in the context of the development of medical devices and innovative treatments on the human body, for which the outcomes are unknown

4 Lord Denning stated '... his incompetent best is not good enough'. Case: Nettleship v. Weston (1971), p. 699.

5 E. Rubinstein, On Medicine and the World of Law in Israel, The Law 2013/8, pp. 645, 658. 
and it is possible that the treatment will not be effective and may even cause harm to the patient. To determine the appropriate way for the performance of innovative treatments and to prevent the filing of unnecessary medical malpractice lawsuits versus the interest of the promotion of the science of medicine, the Public Health Regulations (Medical Experiments on People) ${ }^{6}$ were amended, which emphasize the detailed explanations provided to the patient for the experimental treatment and the patient's informed consent. It is noted that the ruling ${ }^{7}$ deals extensively, to the point of tedium, with cases of medical malpractice in the framework of which the full information was not provided to the client and consequently the principle of informed consent was undermined.

There is an inherent tension between the need to provide a remedy for the harm that originates in medical care and the need to develop medicine, and the climax of the tension is public conflict. Over the years, the State has debated the issue with the goal of halting the economic outcomes of the multiplicity of medical malpractice lawsuits. According to the State Health Insurance Law ${ }^{9}$, the obligation of the State is to provide medical services to its citizens and its residents and to bear the resultant economic burden.

The State Comptroller also addressed the issue and found ${ }^{10}$ that the sums paid for medical malpractice against all the state medical institutions reach billions of shekels. This is perhaps why he called it a wave of lawsuits pertaining not only to the harmed party but also to the public purse. Therefore, the tort of medical malpractice is addressed by the State in its different ministries since naturally the increase of the insurance costs and the compensations amounts is burdensome in the distribution of the resources from the public purse to the health services.

Another aspect regarding lawsuits on the topic of medical malpractice is the issue of the expiration of the grounds, in light of the statute of limitations ${ }^{11}$ and in light of section 89 of the Ordinance, which is the complexity of the discovery

6 Public Health Regulations (Experiments on People) 1980, p. 4189.

7 See for instance: Civil Appeal 560/84 Nachman v. Histadrut Medical Clinic, Court Ruling 40 (2) 384 (1986); Civil Appeal Miasa Ali Daka v. Carmel Hospital Haifa, Court Ruling 53 (4) 526 (1999).

8 See for instance: Report of the Committee for the Examination of the Responsibility for Harm in Medical Treatment under Judge Dr. Gabriel Kling, 10-15 and 51-55 (1999); Government Decision Number 2384 from July 31, 200, following which the Report of the Interoffice Committee for the Examination of the Ways to Reduce the Public Expense for Medical Malpractice, headed by the lawyer Tana Shapnitz, chapter 10 (November 2005).

9 State Medical Insurance Law of 1984 (section 156), p. 68.

10 State Comptroller Report for the Year 2011, Number 2012/62, pp. 197-199.

11 Statute of Limitations of 1958 (section 112), pp. 68, 112. 
of the collection of factors of the grounds regarding the date of the creation and regarding the age of the harmed party. The statute of limitations determines a period of time (for a lawsuit that is not real estate) of seven years from the date the event happened and gives an unlimited grace period to the plaintiff who is not aware of all the facts that caused the harm. However, section 89(2) of the Ordinance reduces and determines a period of ten years from the date the event happened, even if the discovery of the harm occurred later.

It is possible to learn from this that in the tort of negligence, the right of the harmed party is reduced in comparison to other parties, but the courts ${ }^{12}$, which were aware of this outcome, reduced this limitation to a period between the discovery of the relation of the harming party to the harm and the filing of the lawsuit and thus extended the period of the statute of limitations for the tort of negligence. The age of the harmed party is also relevant to this issue, since according to the Statute of Limitations the periods of prescription of the harmed party who has not reached the age of eighteen are not taken into account. Hence, the statute of limitations applies to him in even later stages more regarding the date the event actually happened.

\section{Models in Medical Malpractice}

As was stated above, Articles 35 and 36 of the Ordinance establish the tort of negligent behavior related to causing harm. The wrong is composed of a number of elements which together form a chain: duty of care, guilt (in violating the duty of care), causal relationship, harm. These are familiar elements according to the traditional model in ruling and literature but this is not the only approach to the examination of negligence.

The element of the duty of care is composed of two elements. The first element is the conceptual duty assigned to the person in the aspect of principle, whether it is normatively appropriate to recognize the existence of the duty to act with care ${ }^{13}$ towards another, with the examination of four variables - type of harming party, type of harmed party, type of activity, and type of harm. The second element is

12 For a prominent example of this approach see: Civil Appeal 1254/99 Avigdor HaMeiri v. Hachsharat Yishuv Insurance Company, Court Ruling 54 (2) 535, 2000. In this decision the argument of the defendant that the statute of limitations had expired was rejected, although the lawsuit was filed thirteen years from the event of the harm and it was determined that the period of the statute of limitations had not yet passed from the date at which the causal relationship between the accident and the harm was diagnosed and until the data at which the plaintiff filed his lawsuit and thus the statute of limitations did not expire.

13 Civil Appeal 145/80 Vaknin v. Beit Shemesh Local Council, Court Ruling 37 (1) 113 (1982). 
a concrete duty. If the conceptual duty has been recognized, as state above, then it is necessary to continue examining the existence of the duty under concrete circumstances in the view of the four variables, namely towards the certain harming party, towards the certain harmed party, towards the certain harm, and towards the certain behavior. Under the concrete duty of care, Article 36 of the Ordinance instructs that it is necessary to examine what the harming party, as a reasonable person, could have expected his or her careless behavior to cause.

It is customary to keep in mind that the test of expectations has two dimensions ${ }^{14}$. The first dimension is 'normative expectations': Does society require the harming party to anticipate the risks of harm of the type that occurred in his or her behavior? The second dimension is 'technical expectations': Does the harming party have the ability to expect risks as aforementioned? Either way, it appears that there is overlap between testing the conceptual, ethical question of the duty of care and, on the other hand, normative expectations, which are within the scope of a concrete obligation.

The 'presumption of an obligation' to foresee the type of harms seeks ${ }^{15}$ to establish the social approach, according to which the assignment of responsibility is a desired issue where there is a case of negligence and the negligent individual had the technical ability to foresee the incident, unless there are special considerations of legal policy to negate it. The ability to anticipate the potential harm is a normative filter given to considerations of legal policy, i.e., whether it is appropriate or not to impose responsibility. It should be noted that 'where damage is expected, as a technical matter, there is the conceptual duty of care, unless there are considerations of legal policy that negate the duty ${ }^{16}$.

The element of guilt means the violation of the duty of care by the person obligated to fulfill it along with every person who has relevant legal relations, for example, the corporation, the employer, and so on. The element of guilt does include carelessness, which is not an issue of malice on the part of the harming party, but the tort of negligence can also bear intentional behavior and acts ${ }^{17}$.

14 Civil Appeal 243/83 Municipality of Jerusalem v. Gordon, Court Ruling 39 (1) 113, 128-129 (1985).

15 Civil Appeal 4486/11 Anonymous v. Anonymous, Paragraph 12, Handed down on July 15, 2003.

16 Civil Appeal 4486/11 Anonymous v. Anonymous, Paragraph 12, Handed down on July 15, 2003, P. 131. Also see: Civil Appeal 145/80 Vaknin v. Beit Shemesh Local Council, Court Ruling 37 (1), 113 (1982).

17 For instance: Civil Appeal Amin v. Amin, Court Ruling 53(5) 69, 81 (1999). In addition, for example: Civil Case 1702/07, Ozri v. CanWest Global Communications Corp., pp. 3032, and the introductions, handed down June 20, 2012, section 386 (2) Civil Law of 2011, section 712. 
The violation of the duty of care is not enough, and it is examined with the likelihood of the behavior of the harming party as causing the certain harm to the certain harmed party. The likelihood of the behavior is measured in light of the duty of care that the harmed party undertook or had to undertake and failed to undertake, and accordingly between the characteristics of the specific harming party and the reasonable person with similar characteristics who would have expected such harm at the time of the behavior. It is evident that there is a double causal relationship at play here - the factual and the legal.

A cause-in-fact causation is a test of circumstances in which a certain act is the material cause of an injury or wrongdoing, best known as the 'but-for' test (i.e., had if not been for the specific act having occurred, the injury would not have happened). This constitutes a preliminary condition of the legal causal relationship. Regarding the latter, the rulings ${ }^{18}$ include three cumulative tests:

1. The test of 'reasonable expectations': could the harming party, as a reasonable person, have expected that his or her carelessness would cause harm?

2. Does the damage which is caused fall within the (potential) range of risks which the reckless behavior of the accused causes?

3. The 'common sense' test: did carelessness contribute in actuality to the harm results?

In relation to the comparison of the harming party to a reasonable person, one ruling noted that:

This is also the just, fair, and moral person. This is the person who cares for himself, for others, and for the public, and all of these do not reflect the utmost of his complexity. However, the reasonable person is not the perfect person. This is the person who reflects the complexity of our life, with our qualities and shortcomings, the likelihood therefore expresses the appropriate response of society. This response is always related to the circumstances of the event and it expresses the perception of society regarding social guilt, which is found at the basis of carelessness ${ }^{19}$.

This directive determines a single, uniform level of care. There are no differing standards of reasonable behavior. The determining level of care is that of a reasonable person. This is nothing but a personification of the concept of reasonable-

18 See: Civil Appeal 145/80 Vaknin v. Beit Shemesh Local Council, Court Ruling 37 (1), 113 (1982). Civil Appeal 542/87 Credit and Savings Fund of Reciprocal Association Ltd. V. Mustafa Aoud, Court Ruling 44 (1) 422, 437 (1990), Civil Appeal 2028/99 Peer v. Silovt Building Company (1964) Ltd, Court Ruling 55(3) 493 (2001), Civil Appeal 610/94, Buchinder v. Official Receiver, Court Ruling 57 (4), 289, 311 (2003).

19 Civil Appeal 5604/94, Osama and Ibrahim Hemed v. the State of Israel, Court Ruling 58 (2) 498, Paragraph 16, Court ruling of former President A. Barak (2004). 
ness. This criterion reflects an appropriate balance between the various values and interests to be taken into account. Indeed, reasonableness is not a physical or metaphysical concept. Reasonableness is a normative concept. It is an evaluative process rather than a theoretical one. The reasonableness is not limited by deductive logic. It is determined by identifying the relevant considerations and balancing between them according to their importance ${ }^{20}$.

As we have seen thus far, the test of expectations presides over a number of elements, including the tort of negligence, and it is possible that a feeling of mystery ${ }^{21}$ will arise in light of its complexity and its influence on the results of the trial, since the test presides over the process of the causing and over the process of the harm and its scope encompasses the entire tort: towards the process of the causing, the expectations are not required to be precise but general and the possibility ${ }^{22}$ is enough to predict the occurrence.

Towards the harm and its compensation, Article 76(1) of the Ordinance reduces the expectations by what is called 'distancing the harm' and towards it the harmed party is entitled to payment that naturally is expressed in a regular process of tort behavior. In other words, the harmed party is not responsible and does not bear secondary harms that develop from the primary harms ${ }^{23}$ but the 'natural' ones.

The testing of the concept of the duty of care tests the existence of 'negligence first'. Regarding the complexity of expectations in the tort of negligence, as aforementioned, it was found that the test of normative expectations along with the test of the duty of conceptual care gave a utilitarian advantage to the litigants themselves and to the courts. The combination of both of these together increases the issue for the examination of considerations of legal policy that surmount the assignment of responsibility.

The model of 'negligence first' does not intend to take the place of the traditional model; rather, only in typical and regular places that frequently come before the courts and belong to the core of tort law. The rationale is that with bodily

20 N. MacCormick, On Reasonableness, Revue international de droit comparé 1984, pp. 131, 136.

${ }^{21}$ G. Shani, A. Shmueli, The Servant of Two Masters? The Test of Expectations in the Tort of Negligence, Studies in Law 2011/34, pp. 141, 142.

22 Y. Gilad, The Causality in Israeli Tort Law - Re-examination, Law 1984/14, pp. 15, 26. Also see: Civil Appeal 576/81 Ben Shimon v. Bardeh, Court Ruling 38 (3) 1, 8-9 (1984).

23 Y. Gilad, The Causality in Israeli Tort Law - Re-examination, Law 1984/14\&15, pp. 29-33. Further Civil Appeal 7794/98 Moshe v. Cifford, Court Ruling 57 (4) 721. Y. Gilad, E. Gotel, On the Broadening of the Responsibility in Torts in the Causal Aspect-A Critical Look, Law 2004/34, p. 385. 
harm that comes naturally and for which there is a presumption of obligation, there is no point in discussing every case anew ${ }^{24}$ regarding the existence of duty of care. However, these cases are such that the relations between the harming party and the harmed party are based on law, such as, in this case, the physician and the patient.

\section{Duty of Care in Medical Malpractice}

As previously mentioned ${ }^{25}$, the conceptual duty of care is assigned to every physician regarding his or her patient and there is no need to broaden the legal policy on the topic. This by itself does not indicate that the concrete duty of care is necessarily assigned to the physician towards his or her patient. Litigants must prove that the specific physician had to expect the existence of the certain risk towards their patient ${ }^{26}$.

The recognition of the concrete duty of care can also be enhanced after a single meeting between the physician and the patient. Moreover, as a consequence of the existence of rare illnesses that require expert care, there is a presumption of obligation on the part of the physician.

From the aforementioned presumption of obligation, the physician who has conceptual and concrete duty of care towards his patient in any case, has the duty to adopt the means which another reasonable physician would have adopted under the same circumstances. This is not a sweeping duty or absolute responsibility since the care-providing physician will not be to blame for every illness and every defect ${ }^{27}$. Moreover, not every mistake in judgment of the physician will constitute breach of the duty of care towards the patient since a mistake has a unique weight in reality.

The legal policy requires careful consideration regarding whether a mistake in judgment will necessitate medical malpractice since there is the fear of excessive deterrence in law. The intention is not to weaken physicians or worse still, to bring about a situation in which public medicine operates according to

\footnotetext{
See Civil Appeal 2061/90 Marceli v. State of Israel - Ministry of Education and Culture, Court Ruling 47(1) 802, 809 (1993).

25 Civil Appeal 4025/91 Tzvi v. Dr. Caroll, Court Ruling 50 (3) 784, 788 (1996).

26 Civil Appeal 4025/91 Tzvi v. Dr. Caroll, Court Ruling 50 (3) 789 (1996).

27 Civil Appeal 9656/03 Will of the Deceased Berta Marziano v. Dr. Zinger (Published on Nevo), handed down on April 11, 2005. See also: Civil Appeal 116/89 Andel v. State of Israel, Court Ruling 45 (5) 276, 288 (1991).
} 
an ethos of 'defensive medicine' ${ }^{28}$, according to which, when the physician goes to provide treatment, they will not act only in the interests of providing the best possible care to the patient before them but also will fear the risks of a future lawsuit - and, in this way, as a consequence, society as a whole loses out as the doctor is excessively cautious, preventing the development of medicine.

\section{The Normative Place of the Element of the Harm of Pain and Suffering}

Consistent rulings over numerous years ${ }^{29}$ indicate that for the directly harmed party, it could be that only independent damages are possible, in the format of nonpecuniary harm as deriving from pecuniary harm. Pain and suffering as nonpecuniary harm are recognized if they are an outcome of involvement of the harmed party in the harming party's care or that the harming party is liable towards the harmed party by concern for his or her well being or welfare. Thus, in essence, the feeling of pain and suffering is linked to the physical harm and if the former derives from the existence of the latter, then the liability extends to the prevention of the pain and suffering.

By way of background, the teachings of the philosopher Jeremy Bentham are relevant here. In order to measure the rightness of an action, Bentham asserted that every act must be measured by the amount of pleasure or pain it generates and the number of people who are affected by the action. The pleasure or pain are measured through scientific, accurate tools based on the strength of the pain or pleasure according to certain criteria - The Hedonic Calculus. Amongst these criteria are: intensity, duration, certainty, proximity, fecundity (the chance that pleasure is followed by more pleasure, pain by further pain), purity (the chance that pleasure is followed by pain and vice versa), and extent (the number of people affected). The result of this measure for creating a guiding principle of conduct is simple: every action should aim to cause the greatest amount of happiness for the greatest amount of people and prevent suffering and pain.

28 Civil Appeal 116/89 Andel v. State of Israel, Court Ruling 45 (5) 276, 288 (1991). For an extensive discussion see: Civil Appeal 8591/06 Anonymous v. Madionavest International (1985) Ltd, (Published on Nevo), Paragraph 10 of the ruling of the Respected Judge H. Meltzer, handed down February 9, 2010.

29 See for example: Civil Appeal 4/57 Nadir v. Cahanovitz, Court Ruling 11 1464, 1469 (1957), Civil Appeal 243/83 Jerusalem Municipality v. Gordon, Court Ruling 39 (1) 113, 138-142 (1985), Civil Appeal 2034/98 Amin v. Amin, Court Ruling 53(5) 69 (1999), Civil Appeal 2299/03 State of Israel v. Yafa Terlovsky (Published in Nevo), handed down on January 23, 2007. 
By way of comparison, in ancient Greece, a theory was created by Aristotle known as 'Eudaimonia', meaning self-flourishing. This was a self-realization theory that makes happiness or personal well-being the chief good for man and the perfection of certain virtues.

The impact of these theories is relevant when measuring non-pecuniary harm. From the utilitarian perspective, if our chief priority is the greatest good (understood as the pursuit of pleasure and avoidance of pain), for the greatest number of people, then the pain and suffering felt by the harmed party could be measured against the Hedonic Calculus as a means of guiding us to compensate the harmed party. Equally, in the Aristotelian paradigm, if a person cannot perfect their virtues or 'flourish' and thus realize their full potential due to the damage incurred by the harming party, this prevents them from true happiness and flourishing and needs to be compensated for.

Another foundation of Israeli Law are the principles found in Jewish Law. Within Judaism, there is a specific reference to harm caused by doctors and even expression given to their responsibility when the damage exceeds that which is deemed reasonable: 'A qualified physician who treated a patient with the authority of the court and caused damage, is exempt. However, the doctor who harms a patient more than is appropriate, behold, he is obligated [to compensate the harmed party ${ }^{30}$. Another distinction in Jewish Law is made between intentional and unintentional damage, and thus a physician who treated a patient with the authority of the court and accidentally caused damage is exempt from fault, but a doctor that caused harm intentionally is obligated to compensate the harmed party.

Consequently, those laws in Judaism which absolve the doctor from responsibility relate to damage which is caused as a result of providing reasonable medical treatment. Conversely, laws in Judaism impose tort liability on a physician who provides unreasonable treatment.

The great Jewish thinker and physician Maimonides (The Rambam) addressed the question of the authority of a doctor to treat a person in danger, as authority which is not intended to allow the healing of others, but rather, in order to encourage people to practice medicine and thus remove the physician's fear that perhaps they will make a mistake and be found guilty of causing medical harm, or, god forbid, the killing of a person. The weight of the distinction between a mistake and negligence places a burden on the very practice of medicine. Indeed, this debate has the power to prevent the development of medical error on the grounds that

30 Mishnah, Seder Nezikin, Tractate Bava Kamma, Ch. 9, End of verse 3. 
there is a requirement to allow a doctor to treat - 'Lest the doctor shall say "what do I need this worry for, lest I make a mistake and find myself unintentionally killing a person" " 31 . Thus, the implications for excessive caution when dealing with cases of medical malpractice are very clear within Judaism and the tension between preventing negligence and inhibiting medical development is a challenge.

In order to bring these theories and doctrines into the context of the legal framework, one must consider a solution to the pain and suffering experienced by the harmed party. First and foremost, the primary goal and justification of Tort Law is to restore the harmed party to their original state and only when it is not possible to return the harmed party to their pre-harm state (in property, in body, and in mind), then the realization of the goal is changed to financial values. Other justifications of Tort Law may include the moral obligation to bring about justice and honor the rights of the harmed party as a wronged moral agent. However, the primary focus of this paper is the restoration of the harmed party to their original state. The appropriate rationale ${ }^{32}$ in returning the harmed party to their original state is to put the harmed party in the same financial situation in which he or she would have been, had the harm not be caused, under the title of 'damages'. However, when this is an estimate of the value of the physical harm of the type of pain and suffering, a real difficulty arises regarding the evaluation of the sum of the damages.

How is it possible to evaluate, precisely or even approximately, in money or in monetary equivalent the pain and suffering or sorrow and shame of a person whose hand or foot has been amputated or who walks on his legs but concern eats away at his heart since his days on this earth are numbered? ${ }^{33}$

As stated above, in order to determine the damages for tangible torts, the court has at its disposal legal tools - statistics and evidence about the lifestyles of the harmed party, for instance: livelihood, age, family status, and so on. Thus, in calculating the monetary value of the harm, when the damages are of a nonpecuniary type, the figure is largely speculative, as one ruling stated: 'and the substance remains true much like in the past (then) to this day as fine wine ${ }^{34}$.

31 R. Y. Chaim, Book of Responsa - The Accomplished Person, Light of Life.

32 A. Barak, Evaluation of Compensation in Body Harm: Torts, Desired Situation and Existing Situation, Studies in Law 1983/2, pp. 243, 250. See also: Civil Appeal 357/80 Yeuda Naim v. Moshe Brade, Court Ruling 36 (3) 672, 772 (1982).

33 Civil Appeal 70/52 Grossman v. Rot, Court Ruling 1242, 1254 (1952).

34 Civil Appeal 9927/06 Anonymous v. State of Israel (Published in Takdin), Paragraph 3 of the ruling of Honorable Judge E. Rubinstein, handed down January 18, 2015. 
It would seem that the range of possibilities and situations in which the person might feel pain and suffering because of a wrong is infinite. However, so that this will be compensable and quantifiable, it needs to have real power, which exceeds the response following an elementary human wrong as the part of every living person. The rationale is that although this harm is like nonpecuniary harm, its influence is realized in the world as 'pecuniary' as a type of loss, absence, or expense, as aforementioned in section 2 of the Ordinance. The harm is expressed in a variety of aspects that encompass the lifestyles of the specific harmed party, including their ability to earn a livelihood, potential future earnings, medical treatments, assistance to function normally, and so on.

In his paper ${ }^{35}$ Eliezer Rivlin said that the factors that the Court considers when estimating the head of tort of pain and suffering are: (1) the nature of the harm, (2) the intensity of the harm, and (3) duration of time in which the harmed party felt or continues to feel the harm. These three considerations pertain to the dimension of the result of this unique harm.

To bring about an objective result regarding the estimate of the damage of the physical pain and suffering, the path to which is uniform between the courts and ends in a fair trial, it is important to return to the first principles. Section 2 in the Ordinance defines 'harm' as unlawful touching by legal right, about which it is said 'where there is a right there is a remedy' ${ }^{36}$ (in Latin ubi jus ibiremedium).

Section 1 in the Ordinance presents the Hebrew interpretations of the English terms. Thus, there is value-based difference in the Ordinance: first, the meaning of injury is different from the meaning of damage and second, relief is different from remedy.

Since there is injury in the violation of the duty of care in medical treatment and for this liability is assigned of the type of the tort of medical malpractice, the damages of the pain and suffering that happened to the patient's body are such that they lead naturally to negligent care. As previously described, this is nonpecuniary harm, the existence of which is separate and independent but deriving from the occurrence of the harm as pecuniary harm and according to the Ordinance injury to the body is what calls the damage.

However, the injury itself is not the harm done but rather the harm is the subsequent damage as a result of the injury under the test of expectations, which

35 E. Rivlin, Damages for Non-concrete harm and for nonpecuniary harm - trends of extension, Shamgar Book, Part 3, Tel Aviv, The Israel Bar Publishing House 2003, pp. 21, 61.

36 Civil Appeal Authority 6339/97 Roker v. Salomon, Court Ruling 55 (1) 199, 268, statements of Judge M. Heshin (1999). 
is primarily technical: Can the given damage be caused by the given injury? The three considerations - the nature of the injury, the intensity of the injury, and the duration of time that the harmed party felt it - must be measured against the harmed party's physical situation for the non pecuniary damage.

To illustrate matters, I will provide an example from a case that happened ${ }^{37}$, as follows. A school student in twelfth grade was hurt in his hand by shards of glass. He went to a clinic to remove the glass, had stitches, was bandaged, and was released to his home. For five months he felt pain and returned to the clinic, but this time an x-ray was carried out and a shard of glass was found in his palm. The student was afraid of an immediate operation, and so the surgery was held a month later. In the operation for the removal of the glass an incurable, lifethreatening infection was discovered. The damage was injury to the nerves in the palm, expressed also in physical pain. In the end, it was decided that there was medical malpractice that contributed to exacerbation of the harm, including the duration of time during which the student felt pain. The rate of damages estimated for the persistence of the pain is 70,000 shekels, which was divided among the litigants according to their degree of liability.

The problem is - from what point in time does the damage of the pain begin? The range of possibilities that can be expected from a technical perspective are as follows. First, if the glass shard had been found on the day of the initial treatment, then the damage of the pain would not have been extended. Second, the date of the removal of the shard is not relevant to the damage of the pain since this is caused only because of the penetration of the shard into the palm of the hand. However, the respected court brought to the unfair outcome according to which the medical malpractice extended the time in which the harmed party felt the pains, to the extent of upholding a sort of contribution to an existing injury, otherwise to be found liable in another (the former) injury. To put it simply, if the harm of the pain was caused because the glass shard was left in the palm of the hand and the intensity is what worsened over time, then this is full medical malpractice. Conversely, if the harm of the pain derives from the penetration of the glass, which injured the nerve, then the physician's actions are not causally related to the pain and the physician is fully exempt from the liability for this element. Since it is not possible to go back in time and to discover whether it was possible to prevent the pain with correct medical treatment, the technical expectations necessitate the decisions of a binary outcome, as difficult as it will

Civil Case (Shalom Haifa) 18408/02 Erez Arbel v. Ort Israel City Technological High School (published in Nevo), handed down on July 25, 2005. 
$b^{38}$, namely: either to assign full liability for all of the damage of the pain or to exempt fully from it.

As aforementioned, the test of technical expectations does not require and does not obligate accurate expectations, which give factual certainty between the type of negligent act and the type of damage but the physician's ability to predict that without a reasonable examination, such as a simple $\mathrm{x}$-ray, it is likely that a shard of glass would remain in the body that can cause the damage of pain and suffering to the patient. It has already been determined more than once ${ }^{39}$ that the duty of care is increased when the undertaking of means for the prevention of possible harm is simple.

\section{The Appropriate Legal Approach to the Harm of Pain and Suffering}

As aforementioned, the purpose of Tort Laws is to return the harmed party to the situation that preceded the harm, thus Tort Law not only does not punish the person accused of the harm, but the implications of this, are also that every injured party is a specific, individual case, and the overall enhancing of the harmed party's status is unique to his or her lifestyle. The economic approach to law teaches that the guiding principle in Tort Law is justice which corrects the harm in an equal manner, since this way certainty in law is achieved ${ }^{40}$.

In this situation, the types of harms and the types of harmed parties determine the way in which to set the amount of damages. Therefore, it is necessary to estimate, evaluate, and quantify this in numerical-financial terms. Hence, for the purpose of measuring this harm, it is necessary to consider data prior to the harmed party being injured as well as future implications of the harm on the harmed party. For this purpose, a forecast is necessary, which relies on concrete information about the harmed party and his or her characteristics, which is no more than a hypothesis.

The mechanism of the forecast brings about an undesired result of inequality between the harmed parties, a matter which leads to judicial uncertainty. The

8 Another Civil Hearing 4693/05 Carmel Hospital Haifa v. Malul (published in Nebo) paragraph 16 for the ruling of the honorable judge E. Gronis, handed down on August 29, 2010.

39 See: Civil Appeal 5604/94 Hemed v. State of Israel, Court Ruling 58 (2) 893, paragraph 14 (2004), Civil Appeal 10083/04 Goder v. Modiin Regional Council (published in Takdin) paragraph 12, handed down on September 15, 2005.

40 A. Porat, Tort Law, The Institute for Legislative Research and Comparative Law, Jerusalem 2013 (published in Hebrew). 
estimate of implications of the harm on the harmed party depends on the judicial evaluation of the certain judge in the case and he or she has two tools at their disposal: actuarial-statistical estimate and evidence on the harmed party's lifestyle and global estimate, general data for society. However, even if the actuarial tool maintains the individual purpose of compensating the harmed party, the statistical data cannot predict everything ${ }^{41}$.

One of the problems of the formalism lies in the role of the Court, according to which there are situations in which the performance of the reform or the deviation from it yields an unjust outcome. Thus, the question arises regarding the role of the norm in general and regarding the role of the Courts in particular. One of the ways to cope with these outcomes is the affiliation of the norm to the realms of nature and human morality.

Fundamentally, the approach of legal formalism relies on the linguistic meaning of the language of the law, since in the absence of the directive of the law there is no source for legal obligation. In the intermediate cases, where there is law but the language does not provide a result for the specific case, then the court is required to provide a decision for the sides in a dispute. A realistic decision is based on the doctrine which develops through norms and rulings, which in turn teach about the hierarchy of the norm and its power, so that a 'public' norm will provide a more certain outcome with regard to marginal situations as well. In these cases, in which the medical negligence or malpractice arrives at the court, and there is no historical precedent or specific law to help inform the judge's reasoning, the court decision depends more on the judge's wisdom, beliefs, and values, so that the result is learned only in retrospect but an equivalent binding precedent is lacking.

According to Ronald Dworkin's theory, the process of arriving at a decision is not only through legal rulings but also principles of an abstract nature that complete the act of sentencing. Even in an instance in which there are no rules, these principles are legally binding and therefore the judge should decide that they prevail above all. A judge must always take into account that there will always be a rule or principle that governs and regulates. The rule has first priority but in its absence, it is essential to search for a governing principle.

${ }^{41}$ See: Civil Appeal 10064/02 Migdal Insurance Company v. Rim Abu Hana, Court Ruling 60 (3) 13, Ruling 28 (2005). 
According to Dworkin, the picture is rather blurred concerning the difference between the legal field and other fields. Dworkin claims ${ }^{42}$ that considerations of social justice and social considerations all have a legal status. In this case, he blurs the lines between the law and morality, society and politics. There is a lack of clarity here because if the court brings into its consideration a range of nonlegal principles (including social and political principles of justice), the legal framework lacks a sense of clarity and structure.

Indeed, when illustrating the power of judgement at the disposal of the judge, it is useful to make reference to Neil MacCormick's work. The considerations of morality, here in the context of the judge's moral framework, lean on the power of judgement whose 'locus is intersubjective' ${ }^{43}$. This inter-subjectivity might suggest that it is possible to depend on the judge's beliefs and values for sound reasoning. However, according to MacCormick, as this judgement is not yet a public power of judgement, it cannot be seen as a direct source of legitimation of the law ${ }^{44}$. This generates a challenge when attempting to create a uniform, objective, and universal measure for the compensation of non-pecuniary harm when a precedent is lacking in the law.

In judicial court decisions in Israel, it is evident that the main approach is the middle way, which allows for an appropriate balance between a conflict of interests: namely, on one hand, the interest in avoiding claims that will lead to excessive deterrence and the creation of a phenomenon of overly-protective medicine. On the other hand, the importance of imposing tort liability for the provision of negligent treatment through recognizing the importance of the duty and interest in protecting the patient's rights. One can evidently see that there are numerous considerations from both sides of the argument regarding the imposition of tort liability on doctors.

It appears that even if we follow the law approach, the alignment of values and interests under judicial review requires the court to reach the same result: an unequivocal ruling to both the harming and harmed parties which will allow them both to continue their previous lifestyle. This is a tension between the law and reality and the figure of the judge obligates a decisive and certain solution alongside a place for agreements between the sides themselves.

42 R. Dworkin, Justice for Hedgehogs, The Belknap Press of Harvard University Press, Cambridge, Massachusetts 2011.

43 N. MacCormick, Practical Reason in Law and Morality, Oxford University Press, Oxford, New York 2008, p. 29.

${ }^{44}$ N. MacCormick, Institutions of Law. An Essay in Legal Theory, Oxford University Press, Oxford, New York 2008. 


\section{References}

\section{Legal Rulings}

Another Civil Hearing 4693/05 Carmel Hospital Haifa v. Malul (published in Nebo) paragraph 16 for the ruling of the honorable judge E. Gronis, handed down on August 29, 2010.

Civil Appeal 10064/02 Migdal Insurance Company v. Rim Abu Hana, Court Ruling 60 (3) 13, Ruling 28 (2005).

Civil Appeal 10083/04 Goder v. Modiin Regional Council (published in Takdin) paragraph 12, handed down on September 15, 2005.

Civil Appeal 116/89 Andel v. State of Israel, Court Ruling 45 (5) 276, 288 (1991).

Civil Appeal 1254/99 Avigdor HaMeiri v. HachsharatYishuv Insurance Company, Court Ruling 54 (2) $535,2000$.

Civil Appeal 145/80 Vaknin v. Beit Shemesh Local Council, Court Ruling 37 (1) 113 (1982).

Civil Appeal 2034/98 Amin v. Amin, Court Ruling 53(5) 69 (1999).

Civil Appeal 2061/90 Marceli v. State of Israel - Ministry of Education and Culture, Court Ruling 47)1) 802, 809 (1993).

Civil Appeal 2299/03 State of Israel v. Yafa Terlovsky (Published in Nevo), handed down on January 23, 2007.

Civil Appeal 243/83 Jerusalem Municipality v. Gordon, Court Ruling 39(1) 113, 138-142 (1985).

Civil Appeal 243/83 Municipality of Jerusalem v. Gordon, Court Ruling 39 (1) 113, 128-129 (1985).

Civil Appeal 357/80 Yeuda Naim v. Moshe Brade, Court Ruling 36 (3) 672, 772 (1982).

Civil Appeal 4/57 Nadir v. Cahanovitz, Court Ruling 11 1464, 1469 (1957).

Civil Appeal 4025/91 Tzvi v. Dr. Caroll, Court Ruling 50(3) 789 (1996).

Civil Appeal 4486/11 Anonymous v. Anonymous, Paragraph 12, Handed down on July 15, 2003.

Civil Appeal 560/84 Nachman v. Histadrut Medical Clinic, Court Ruling 40 (2) 384 (1986).

Civil Appeal 5604/94 Hemed v. State of Israel, Court Ruling 58 (2) 893, paragraph 14 (2004).

Civil Appeal 5604/94 Osama and Ibrahim Hemed v. the State of Israel, Court Ruling 58 (2) 498, Paragraph 16, Court ruling of the then President A. Barak (2004).

Civil Appeal 5604/94 Osama and Ibrahim Hemed v. the State of Israel.

Civil Appeal 576/81 Ben Shimon v. Bardeh, Court Ruling 38 (3) 1, 8-9, (1984).

Civil Appeal 70/52 Grossman v. Rot, Court Ruling 1242, 1254 (1952).

Civil Appeal 8591/06 Anonymous v. Madionavest International (1985) Lts, (Published on Nevo), Paragraph 10 of the ruling of the Respected Judge H. Meltzer, handed down February 9, 2010.

Civil Appeal 9656/03 Will of the Deceased Berta Marziano v. Dr. Zinger (Published on Nevo), handed down on April 11, 2005.

Civil Appeal 9927/06 Anonymous v. State of Israel (Published in Takdin), Paragraph 3 of the ruling of Honorable Judge E. Rubinstein, handed down January 18, 2015.

Civil Appeal Amin v. Amin, Court Ruling 53 (5) 69, 81 (1999).

Civil Appeal Authority 6339/97 Roker v. Salomon, Court Ruling 55 (1) 199, 268, statements of Judge M. Heshin (1999).

Civil Appeal Miasa Ali Daka v. Carmel Hospital Haifa, Court Ruling 53 (4) 526 (1999).

Civil Case (Shalom Haifa) 18408/02 Erez Arbel v. Ort Israel City Technological High School (published in Nevo), handed down on July 25, 2005. 
Civil Case 1702/07 Ozri v. CanWest Global Communications Corp. pp. 3032, and the introductions, handed down June 20, 2012, section 386(2) Civil Law, 2011, section 712.

Civil Wrongs Ordinance, 1380, 1 (93) (A) 129.

Court Ruling 58 (2) 498, Paragraph 16, Court ruling of the then President A. Barak (2004).

Further Civil Appeal 7794/98 Moshe v. Cifford, Court Ruling 57 (4) 721.

\section{Laws}

Patient's Rights Law, 1966, 68327.

Public Health Ordinance, 1065, 1 (60) 191 (1) 239.

Public Health Regulations (Registration of Clinics), 1987, regulations file 5049.

Public Health Regulations (Experiments on People), 1980, regulations file 4189.

State Medical Insurance Law, 1984, 68156.

Statute of Limitations, 1958, 68112.

\section{Literature}

Ajzenstadt Mimi, Rosenhek Zeev, Privatization and New Modes of State Intervention: The Long-Term Care Program in Israel, Journal of Social Policy 2000/92.

Barak Aharon, Evaluation of Compensation in Body Harm: Torts, Desired Situation and Existing Situation, Studies in Law 1983/2.

Dworkin Ronald, Justice for Hedgehogs, The Belknap Press of Harvard University Press, Cambridge, Massachusetts 2011.

Gilad Yisrael, Gotel Ehud, On the Broadening of the Responsibility in Torts in the Causal Aspect-A Critical Look, Law 2004/34.

Gilad Yisrael, The Causality in Israeli Tort Law - Re-examination, Law 1984/14.

Haim Rabbi Yosef, Questions and Answers: Many Wonders.

MacCormick Neil, Institutions of Law. An Essay in Legal Theory, Oxford University Press, Oxford, New York 2008.

MacCormick Neil, On Reasonableness, Revue internationale de droit comparé, 1984.

MacCormick Neil, Practical Reason in Law and Morality, Oxford University Press, Oxford, New York 2008.

Porat Ariel, Tort Law, The Institute for Legislative Research and Comparative Law, Jerusalem 2013 (published in Hebrew).

Rivlin Eliezer, Damages for Non-concrete harm and for nonpecuniary harm - trends of extension, Shamgar Book, Part 3, Tel Aviv, The Israel Bar Publishing House 2003.

Rubinstein Eliyakim, On Medicine and the World of Law in Israel, The Law 2013/8.

Shalev Michael, Political Economics, in: Nitza Berkovitz, Uri Ram (eds.), Inequality Lexicon, Ben-Gurion University Press, Beer Sheva 2006.

Shani Guy, Shmueli Amir, The Servant of Two Masters? The Test of Expectations in the Tort of Negligence, Studies in Law 2011.

\section{Other}

Government Decision Number 2384 from July 31, 200, following which the Report of the Interoffice Committee for the Examination of the Ways to Reduce the Public Expense for Medical Malpractice, headed by the lawyer Tana Shapnitz, chapter 10 (November 2005).

State Comptroller Report for the Year 2011, Number 62/2012.

Report of the Committee for the Examination of the Responsibility for Harm in Medical Treatment under Judge Dr. Gabriel Kling, 1999. 
Natali LEVIN

\title{
DELIKTY W PRAWIE IZRAELSKIM. ZADOŚĆUCZYNIENIE ZA SZKODĘ NIEMAJĄTKOWA W WYNIKU MEDYCZNYCH ZANIEDBAŃ
}

\author{
(Streszczenie)
}

Artykuł omawia trudne i zawiłe aspekty problematyki zadośćuczynienia za szkodę niemajątkową w wyniku doznania bólu i cierpienia, które są objęte zakresem norm prawa izraelskiego. Do dnia dzisiejszego nie ma jasno określonych prawnych reguł oceny szkody niemajątkowej, w szczególności bólu czy cierpienia. W związku z tym poszukujemy orzeczeń różniących się znacząco, a mających za swój przedmiot szkody powstałe w bardzo podobnych okolicznościach. Orzeczenia takie wskazują na zindywidualizowany charakter każdej ze spraw mających za swój przedmiot zagadnienie krzywdy. Ekonomiczne podejście do prawa wskazuje, że naczelną zasadą w prawie deliktów jest reguła sprawiedliwości wyrównawczej, a zatem i pewności prawa. Jednakże w obliczu braku dobrze zdefiniowanych reguł prawnych w ramach szkód niemajątkowych podejście ekonomiczne jest nieosiagalne. Jedynym możliwym rozwiązaniem jest każdorazowa analiza czynników wchodzących $\mathrm{w}$ grę w indywidualnych przypadkach, aby określić kwotę kompensacji.

Slowa kluczowe: delikty; medyczne zaniedbania w Izraelu; szkoda majątkowa i niemajątkowa 